struggling in the most fateful way: one, which unites synthesis and analysis, which seeks the truth of to-morrow, which has nothing to do with politics and political parties; the other, which is entirely subjective, full of personal ambitions and views, which is devoid of analytic conceptions, and is born of the evils of to-day.

Science is struggling with politics for its freedom; politics is struggling with science for its triumph. It is a struggle which, alas! human history has witnessed many times, but which has always ended in victory for science. It did seem that this useless struggle would not have to repeat itself again; yet now the fierce combat is going on in Russia; the old times of the Middle Ages have once more returned on the earth. The Bolshevists are repeating in many ways the long-forgotten past, though they themselves are convinced that for the first time they are propagating a new creed.

\title{
Physical Effects Possibly Produced by Vision observed by Dr. Russ.
}

\author{
By Dr. H. Hartridge.
}

$T^{\mathrm{H}}$ $\mathrm{HE}$ rise and fall of scientific theories forms a topic for study almost as interesting as does the supersedence in history of one dynasty by another. Newton's corpuscular theory of light was displaced by the wave theory in much the same way as the teaching of Aristotle supplanted the older view of Plato-that in vision emanations proceed forth from the eye to strike the objects looked at. But just as modern physical research has revived certain aspects of the corpuscular theory, so the researches of Dr. C. Russ ("An Instrument which is Set in Motion by Vision or by Proximity of the Human Body," Lancet, July 30, p. 222) have recalled to memory the views of Plato. For these researches have shown that certain instruments react when the human eye is directed at them.

One instrument used.by Dr. Russ consisted of a solenoid suspended by a single fibre of unspun silk within a case composed partly of glass and partly of metal, in such a way that the contents were shielded from air-currents. Above the solenoid was mounted a small permanent magnet, so that the suspended solenoid set itself in a constant meridian under the earth's magnetic field. In another instrument the solenoid was replaced by a condenser, oppositely charged metal plates being mounted outside the instrument-case. With both instruments it was shown that a rotation of the suspended system occurred when the gaze was suitably directed through a slot in the outside casing. As to the precise details of the rotation, the description is not very clear, but it seems that when the gaze was directed to the centre of the suspended system no rotation occurred; when, however, the gaze was directed on either side of the system, then that side rotated away from the eyes some io to 45 degrees, and then again came to rest. If the gaze continued to act, the deflection remained unaltered; but if the eyes were then closed, the index returned to zero.

In earlier experiments the rotation of the instrument was directly observed by the human eye; later, however, the instruments were fitted with concave mirrors similar to those applied to reflect- ing galvanometers, so that the rotation could be measured in the ordinary way by the movement of a spot of light on a scale. Besides demonstrating that rotation of the instruments occurred under the action of the gaze, 'Dr. Russ also found somewhat similar effects if the fingers were held near the instrument.

Nothing definite is known at present as to the explanation of these effects, but Dr. Russ made the following preliminary alternative sugges. tions :-

I. That the effects are due to changes of temperature.

2. That they are due to the electrical changes which accompany vision and muscular action.

3. That electrostatic forces are responsible for them.

4. That the eye may emit electromagnetic waves (e.g.. visual, infra-red, ultra-violet, and X-rays).

With regard to the above suggestions, it may be said that temperature changes are not likely to be the cause, for hot objects placed in suitable positions near the instruments produced either no effects, or effects very much smaller than those producible by eye or hand. Electric changes produced in muscle or in eye can, I think, be safely ruled out, because of their smallness and because of the closed circuits which the connective tissues, skin, etc., form over them. To demonstrate or to measure these currents, the retinæ or muscles must themselves be connected to the leads of the galvanometer. Dr. Russ apparently ruled out the possibility of electrostatic changes being responsible, by finding that the directing of the gaze through a fine metal grid connected to earth (which would screen off electrostatic charges) did not prevent the instruments from reacting to the gaze as usual.

Lastly, in favour of the effect being an optical one ( $\mathrm{I}$ intend $\mathrm{X}$-rays to be included) are the following facts found by Dr. Russ :-

I. That interposing a column of water between the eye and the instrument reduced the effects.

2. That the effects are very much smaller, or No. 2705 , vol. In8] 
are quite absent, in the dark. (Dr. Russ's words are: "I did four tests which seemed to give a positive effect.")

3. That if a strong beam of light be allowed to fall on the suspended system of the instruments the gaze has no longer any effect.

There are no grounds on which a definite conclusion can be based, but I think the inference is that the effect is an optical one.

Measurements should therefore be made to see what electromagnetic rays are responsible for the effects. (I) Are they stopped by a thick slab of lead glass? If they are, they are probably X-rays. (2) Are they stopped by æsculin or by $\beta$ naphthol disulphonic acid? If they are, they are probably ultra-violet rays. (3) Are they stopped by strong methyl-violet? If so, visual rays may be responsible. (4) Are they stopped by a saturated solution of ferrous sulphate in water? If so, then they may be infra-red rays.

In the next place tests should be applied to see if the rays obey the ordinary laws of $(a)$ reflection, $(b)$ refraction, $(c)$ polarisation, $(d)$ inverse squares. In fact, everything should be done to correlate Dr. Russ's observations with known physical laws, before metaphysical explanations are even thought of. Since writing the above I have seen a letter in the Lancet of August 6 in which Dr. J. D. Suttie points out that another conclusion can be drawn from Dr. Russ's experiments. For example, in the experiment in which he found that the side of the solenoid looked at rotated away from him, what Dr. Russ was really doing was to place the fixation point of his fovea co-ordinate with the side looked at. But Dr. Suttie observes that all other parts of the solenoid would be equally co-ordinate with some other part of the retina, and that if all parts of the retina were equally active there is no reason why any movement should take place, since the forces on the two sides would balance. Therefore he argues that the effects obtained by Dr. Russ drive us to the conclusion that the fovea is very superior to the rest of the retina in the degree of its activity [If it were very inferior, the same explanation would equally hold good.-H. H.], and holds further that the force ("if there be such") "is refracted by the optical media of the eye in a manner similar to light."

Dr. Suttie then goes on to suggest that "the deviation [refraction by optical media?] of the force would supply a valuable clue as to its nature, and that obvious controls would be to test persons whose retinas are inactive through disease, or who suffer from opacity of the eye media (e.g. cataracts)." With these points of Dr. Suttie's letter I entirely concur.

In his reply to Dr. Suttie's letter Dr. Russ (Lancet, August I3) writes: "His [Dr. Suttie's] reference to cataracts as controls is surely a feeble suggestion." To me, at all events, it seems clear that Dr. Russ has entirely missed the point of Dr. Suttie's suggestion, viz. that tests on an eye with a cataract would decide whether the effects found by Dr. Russ are due to forces originating from eye structures lying in front of or behind the crystalline lens. Surely not a "feeble" suggestion at all, but a very valuable one! It seems to me that it is not in regard to this suggestion alone that Dr. Russ has misunderstood Dr. Suttie.

\section{Obituary.}

Prof. G. T. LAdD.

$D_{\text {died at New Haven, Connecticut, on }}^{\text {R. at }}$ August 8 , was born at Painesville, Lake County, Ohio, in 1842 . In 1879 he became professor of philosophy at Bowdoin College, and two years afterwards, in $188 \mathrm{I}$, was appointed to the chair of philosophy at Yale. Later he was elected Clark professor of metaphysics and moral philosophy at the same university, a position which he occupied until 1905, when, on his retirement, he received the title of emeritus professor. As a lecturer Prof. Ladd was well known in other countries besides America. Three times-in 1892, 1899, and 1907 -he gave courses of lectures in Japan, and in 1899 and I90o he visited India, lecturing in philosophy at the University of Bombay, and in the philosophy of religion at Calcutta and elsewhere. $\mathrm{He}$ was in England in I9II, and was present at the first of $M$. Bergson's lectures on the nature of the soul at University College, London, in the October of that year. His writings are numerous, and many of them voluminous. Certain of his books have been widely used in the universities of the United States and of this country.

So far back as 1887 Prof. Ladd published his "Elements of Physiological Psychology," which was based, to a large extent, upon the second edition of Wundt's "Grundzüge," but had distinct merits of its own as an independent compendium and discussion of the psychophysical material then available. A revised edition appeared in rgrr. A more important and original work of his is that which saw the light in 1894, "Psychology, Descriptive and Explanatory"as was said of it at the time: "Literally a weighty production, it turns the scale at three pounds avoirdupois."

Prof. James Ward's Encyclopædia article had appeared nine years before, yet Prof. Ladd's volume, in certain respects, broke new ground, to which, however, Prof. Ward's article had obviously prepared the way. In particular, the divisions of the book involved the complete abandonment of the old and vicious doctrine of "faculties," and in it the conception was consistently adopted that the formation and development of a so-called faculty were themselves 